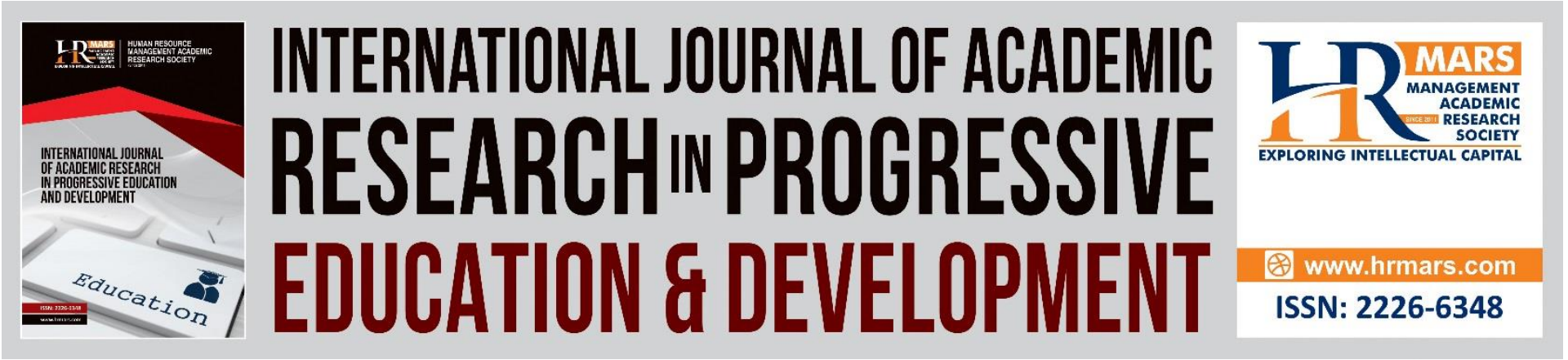

\title{
Blended Learning in Technical and Vocational Education and Training (TVET) Training Institute
}

Norliza Hashim, Zahari Hamidon

To Link this Article: http://dx.doi.org/10.6007/IJARPED/v11-i1/12343

DOI:10.6007/IJARPED/v11-i1/12343

Received: 18 November 2021, Revised: 23 December 2021, Accepted: 10 January 2022

Published Online: 30 January 2022

In-Text Citation: (Hashim \& Hamidon, 2022)

To Cite this Article: Hashim, N., \& Hamidon, Z. (2022). Blended Learning in Technical and Vocational Education and Training (TVET) Training Institute. International Journal of Academic Research in Progressive Education and Development, 11(1), 837-860.

Copyright: (C) 2022 The Author(s)

Published by Human Resource Management Academic Research Society (www.hrmars.com)

This article is published under the Creative Commons Attribution (CC BY 4.0) license. Anyone may reproduce, distribute, translate and create derivative works of this article (for both commercial and non-commercial purposes), subject to full attribution to the original publication and authors. The full terms of this license may be seen

at: http://creativecommons.org/licences/by/4.0/legalcode

Vol. 11(1) 2022, Pg. 837 - 860

http://hrmars.com/index.php/pages/detail/IJARPED

JOURNAL HOMEPAGE

Full Terms \& Conditions of access and use can be found at http://hrmars.com/index.php/pages/detail/publication-ethics 


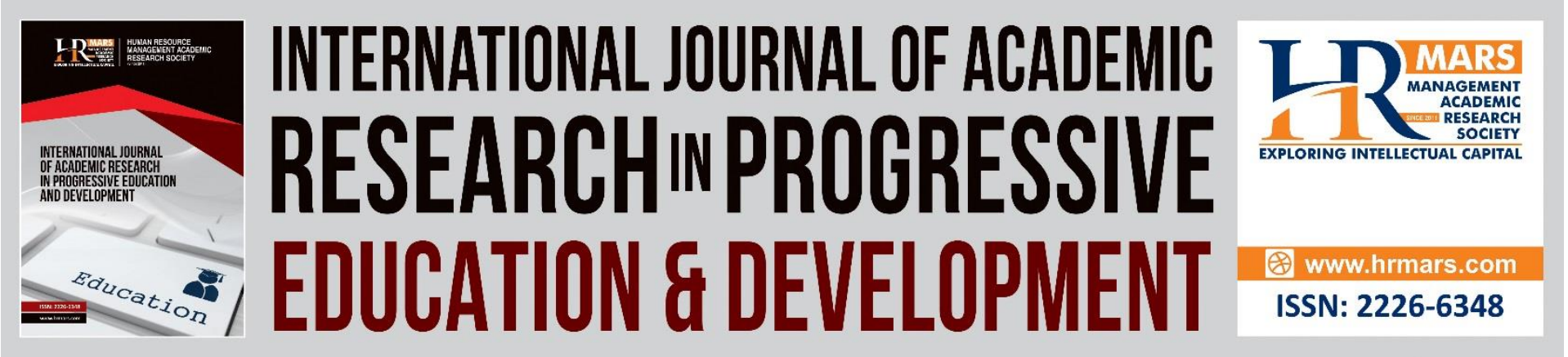

\title{
Blended Learning in Technical and Vocational Education and Training (TVET) Training Institute
}

\author{
Norliza Hashim, Zahari Hamidon \\ Open University Malaysia
}

\begin{abstract}
This paper discusses blended learning in Technical and Vocational Education and Training (TVET) Training Institute. Blended learning is an approach of teaching and learning that combines different technologies and methods to improve the educational experience in TVET. Blended learning in TVET can be categorised into three models; learning in classroom and workshop enhanced with technology, on- the-job training supplemented with classroom, distance and online learning as well as fully distance and online learning. ADDIE model is applied alongside Google Classroom as a blended learning platform in TVET institution as an initiative to meet the challenges of $21^{\text {st }}$ century learning skills. During the COVID-19 pandemic, most of the TVET institutions implement blended learning method to conduct their training and theory courses online.
\end{abstract}

Keywords: Blended Learning, COVID-19, Google Classroom, Online learning, TVET

Introduction

The Malaysia government's aspiration is to create a higher education system that ranks among the world's leading education systems. Malaysian Higher Education Blueprint (2015-2025) launched by the Ministry of Education has outlined 10 shifts that will support a continuous distinction in the higher education system. These 10 shifts focus on the outcomes for the stakeholders and enablers for the higher education ecosystem such as financial funding, governance, innovation, global prominence, globalised online learning and transformed higher education delivery.

Malaysia aspires to be an online education hub through globalised online learning. There are three strategies and initiatives within this Shift:

i. ICT-enable learning to have enormous transformative potential. It enables greater personalisation of the learning experience and increases student-educator interaction. This model is only expected to grow in importance, particularly among the new generation of digital natives.

ii. A blended learning model which integrates the best of ICT-enable learning face-toface instruction. The pedagogical models create an engaging learning environment and enhance the quality of teaching and learning. 


\section{DEVELOPMENT}

Vol. 11, No. 1, 2022, E-ISSN: 2226-6348 @ 2022 HRMARS

iii. Online learning as a key enabler for the other Shifts. Globalise online learning can widen the access to higher education in a cost-effective manner and increase the visibility of Malaysia's higher education brand.

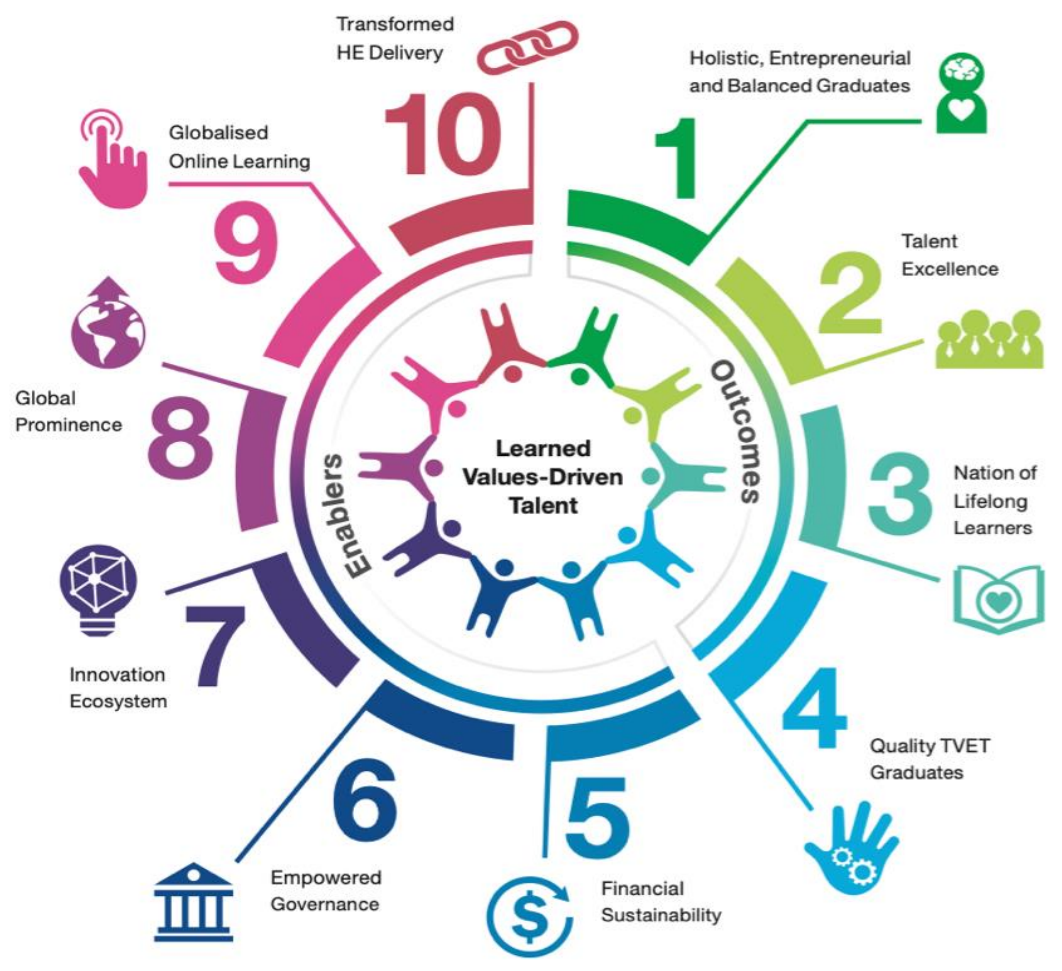

Figure 1: Malaysia Education Blueprint 2015-2025 (higher education)

(https://www.um.edu.my/docs/default-source/about-um_document/media-centre/ummagazine/4-executive-summary-pppm-2015-2025. pdf?sfvrsn=4)

The blended learning model is one of the Global Online Learning strategies. The Ministry of Education developed a strategic plan for blended learning implementation. The Malaysia Education Blueprint 2015-2025 (higher education) highlights 4 main guidelines to transform TVET as an important pathway for vocational education and skills development and lifelong learning. The use of ICT such as blended learning method increases the lifelong learning opportunity in TVET system. According to the United Nations Educational, Scientific and Cultural Organization (UNESCO) (2015), blended learning is one of the prominent initiatives to enable the ICT integration in TVET.

The Malaysia Education Blueprint strategies and corresponding initiatives are in line with UNESCO's Recommendation on TVET which includes:

i. Strategy A: Enhancing industry-led curriculum

ii. Strategy B: Creating integrated and coordinated governance structure

iii. Strategy C: Streamlining qualifications

iv. Strategy D: Rebranding of TVET 
DEVELOPMENT

Vol. 11, No. 1, 2022, E-ISSN: 2226-6348 @ 2022 HRMARS

Blended Learning

Blended learning is a new method in educational institution to assist educators to equip students with $21^{\text {st }}$ century learning skills. A combination of classroom and web-based teaching offers widest range of learning modes and methods for developing students' knowledge and skills (Means et al., 2009). There are several findings from previous literatures that found blended learning nurtures learner's ability to learn collaboratively, think creatively, study independently and make their own learning experiences to meet their individual needs.

Blended learning is a combination of various teaching delivery. Garrison and Vaughan (2006); Neals (2010) defined blended learning as a student-centred, self-paced, flexible, and multi-model approach to learning. Blended learning is an interconnection of face-to-face mode of teaching with Web-based teaching and learning. For example, the students attend the physical classes and at the same time complete the online components independently outside the classroom on an online learning platform. According to Garrison and Kanuka (2004), blended learning is a mixture of physical classroom activities supported by online technology and further develop into an integration of learning activities between students and instructors.

According to Vaughan, Innes and Garrison (2013), blended learning is the inspiration of the innovation both pedagogically and technologically in higher education. The innovation utilises the internet technology to create online learning platforms. The students then are involved in online learning activities which the course contents are provided by the instructors. Rosen and Stewart (2015) explained that blended learning is a solution that minimises the geographical distance issue and combines the face-to-face classes with online component.

According to Adams Becker et al (2018), blended learning design is the primary option in higher education today due to their prominent role in increasing the flexibility and convenience of the students. Blended learning is the innovation and transformation of education in the $21^{\text {st }}$ century. Blended learning also includes personal quality learning, which facilitates, engages, and supports tailored learning experience. UNESCO and the Commonwealth of Learning ( $\mathrm{COL}$ ) emphasise this approach, as it makes learning become more flexible than before. This method will facilitate the students to be part of the digital community. Baditvilai (2016) stated that a blended learning environment not only includes the physical presence of teachers and students, but also students' ownership and mastery of their time, place, setting, path and learning speed.

The Commonwealth of Learning (2015) defined blended learning as an approach to teaching and learning that combines different technologies, methods, and resources to improve students' educational experience. Hybrid learning is defined as any online activities that are augmented by classroom meetings and replace a significant percentage of required face-to-face interaction (Online Learning Consortium, 2015). In other words, although most of the course activity is done online, face-to-face interaction is still required for certain activities such as hands on lab, practical and in-person learning activities.

Theories of Blended Learning 
DEVELOPMENT

Vol. 11, No. 1, 2022, E-ISSN: 2226-6348 @ 2022 HRMARS

There are three main learning theories which serve as the foundation for blended learning, which are behaviourism, cognitivism and social constructivism. According to Norliza and Nornihla (2020), these theories are important for developing online material and instructional strategies. Behaviourism learning theory focuses on the human behaviour which concentrates on observing students respond to certain stimuli, when repeated, can be assessed, quantified and eventually controlled for each individual.

The prominent philosophers in behaviourism theory are Ivan Pavlov, B.F Skinner and Edward Thorndike. Ivan Pavlov is well known for his famous experiments with dogs, food and audible stimuli such as a bell. B.F. Skinner introduced the operant conditioning which emphasised the use of both positive and negative reinforcement to help individuals learning new behaviour. This operant condition had a significant influence on the early ComputerAssisted Instruction (CAI) models which evolved to an attempt for programmed instruction. This CAl models are programmed to give predetermined paths to follow and allow the students to proceed only when the correct answer is given. The behaviourism approach focuses on guiding students to reach pre-establish learning outcomes. Therefore, the behaviourism approach for blended learning must provide students with the appropriate stimuli and these opportunities help them to demonstrate their understanding about the lecture.

Cognitivism theories focus on identifying mental processes such as how information is received, organised, stored and retrieved. Cognitivism also pays attention on what students know and how they come to acquire what they know. Cognitive principles according to Greitzer (2002) can guide the design of active learning applications. Interaction is the basis of student-centred/active learning. For example, cognitive principles are used in multimedia technology to implement interaction elements which support scenario-based training. The interactive images, 3-D modelling and movies are useful for technical computer-based training or Web-based e-learning. Therefore, it is relevant to utilise blended learning training solutions that employ a combination of classroom instruction and e-learning (Greitzer et.al, 2003).

Bloom's taxonomy is the taxonomy of learning that relates to intellectual skill development and highlights problem solving as a higher order skill (Benjamin Bloom, 1965). The six key elements are creating, evaluating, analysing, applying, understanding and remembering. Constructivism is the learning theory suited to the traditional classroom According to Hoic-Bozic (2009) learning system should include the element of behaviourism, cognitivism and constructivism but in today's context, constructivism is the most widely accepted model learning in education. Gulati (2008) stated that learning theories that is used in online content creation are considered a socially constructive experience. The students are engaged with their peers through online medium or through blended learning of online and traditional classes.

The preceding learning theories contribute to the evolution of the current learning theories that suit online environment. The theories are:

i. Community of Inquiry (COI): A model for online learning environment developed by Garrison, Anderson \& Archer (2000) based on the concept of three different 
presences, cognitive, social and teaching. This model supports the design of online and blended learning as an active learning environment dependent on instructors and students sharing their ideas, information and opinion.

ii. Connectivism: George Siemens (2004) who is the pioneer of the early MOOC has been the main advocate of connectivism learning models that acknowledge the major shift in the way knowledge and information flows, grows and changes because of the vast data communication network.

iii. Online Collaborative Learning: This theory proposed by Harasim (2017) that focuses on collaborative learning, knowledge building and Internet use to reshape formal, non-formal and informal education for the Knowledge Age.

There are many theories that can be associated with online learning. Therefore, the blended learning theories can be the integrated theory from the major learning theories.

Blended Learning Model

Blended learning is also identified as hybrid or mixed-mode learning. This instructional design system uses various teaching and learning experiences and the design as well as implementation are varied across teachers, programs and schools. Blended learning can be divided into three main models as shown in Figure 2 below.

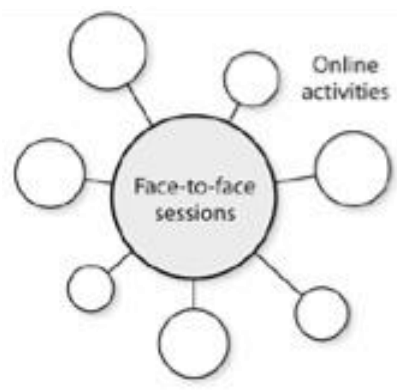

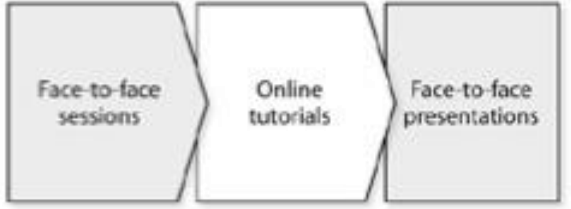

Figure 2: Models of Blended learning

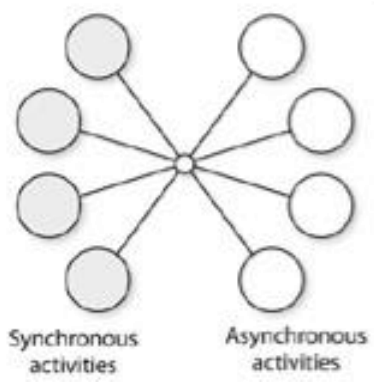
activities

(Guide to Blended Learning, Innes and Wilton, 2018)

The first model is blended presentation and interaction. Classroom engagements are the primary component of this model with support from out-of-class interaction and online exercises. The example is flipped classroom or flipped curriculum where students view the online resources independently then followed by classroom-based tutorials.

The second model is blended block, a sequence of activities or blocks structured to combine face-to-face learning and online study, usually considering both pedagogical goals and practical constraints. For example, students may have limited opportunities for classroom-based learning due to the geographical factor which limits intensive face-to-face session followed by block online study and collaboration via online tutorials, possibly followed by a further block of face-to-face group presentation.

The third model is fully online, which incorporates both synchronous learning and asynchronous activities. Therefore, blended learning covers by following three situations: 


\section{DEVELOPMENT}

Vol. 11, No. 1, 2022, E-ISSN: 2226-6348 @ 2022 HRMARS

i. Combines teaching methods (or delivery media).

ii. Combines instructional methods.

iii. Combines online and face-to-face instruction.

\begin{tabular}{|c|c|c|}
\hline MODEL 1 & MODEL 2 & MODEL 3 \\
\hline $\begin{array}{l}\text { Blended presentation and } \\
\text { interaction }\end{array}$ & Blended block & Fully online \\
\hline $\begin{array}{l}\text { Activity-focused face-to-face } \\
\text { sessions blended with online } \\
\text { resources. } \\
\text { For example, the flipped } \\
\text { curriculum model combines } \\
\text { short lecture podcasts, online } \\
\text { resources with face-to-face } \\
\text { tutorial or seminars for } \\
\text { interaction and presentation of } \\
\text { group work. }\end{array}$ & $\begin{array}{l}\text { Combination of: } \\
\text { - intensive face-to-face } \\
\text { sessions as one day or } \\
\text { half days } \\
\text { - weekly online } \\
\text { tutorial/seminars for } \\
\text { activities and interaction } \\
\text { - online content and } \\
\text { resources }\end{array}$ & $\begin{array}{l}\text { Combination of: } \\
\text { - short lecture podcasts } \\
\text { with online resources } \\
\text { and learning activities } \\
\text { - online tutorials } \\
\text { (synchronous) } \\
\text { - interaction via online } \\
\text { collaboration, discussion } \\
\text { forums and/or group } \\
\text { work }\end{array}$ \\
\hline
\end{tabular}

Table 1: Three models of blended learning (Hannon \& Macken, 2014)

The Clayton Christensen Institute describes blended learning model. There are four models in blended learning.

i. Rotation Models: The students have several stations rotation on a regular schedule. One of the rotation stations must be an online learning station. There are subclasses of the rotation model:

- Station Rotation: The students rotate between several of the station. One of rotation the station includes an online learning component. Other station involves traditional approaches such as group discussion, worksheet and small work group.

- Lab Rotation: The online component occurs in a learning lab that is designed especially for this purpose. Students rotate between classroom and lab learning environments during their staying in the campus.

- Flipped Classroom: The students rotate on a regular schedule between classroom instruction during the school hour and online outside the school hours. Students control their own way how, when and where they receive their online instruction and rotate back to the classroom environment to apply what they have learned in the project-based environment.

- Individual Rotation: In this model, students customise how they rotate between modalities and again, one of which is necessary online learning.

ii. Flex model: Students use different learning resources sensuously as needed. Most of the resources are available online and instructors provide instruction as needed to supplement 


\section{DEVELOPMENT}

Vol. 11, No. 1, 2022, E-ISSN: 2226-6348 @ 2022 HRMARS

online work. The students still learn in a brick- and -mortar environment with the teacher on the site, but assignments are submitted via an online platform.

iii. A La Carte model: This model is also known as the "self-bend" model. This model allows students to design their own educational experiences by selecting online courses to enhance their traditional in school coursework. The teaching recording is virtual and learning occurs either at school or home for their online coursework component. According to Murphy et al (2017), Adult Basic Education programmes in the US refers this model as enrolment or hybrid learning.

iv. Enriched Virtual model: In this model, students learn mostly in online mode, but they need to divide their time between the brick-and-mortar school campus and off-site environment. This is a whole school experience which means that it is a comprehensive approach to school (compared to course by course approach to self-blend model). Teaches are visually recorded, although teachers or paraprofessional provide additional support within the brick and mortar environment as well.

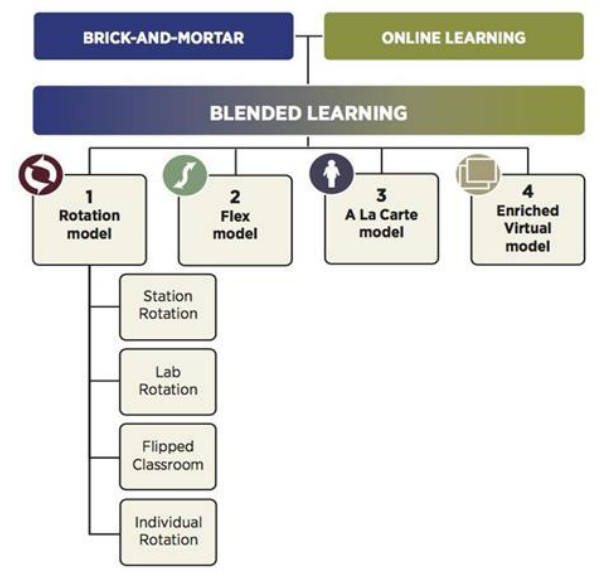

Figure 3: The four models of blended learning

(https://www.christenseninstitute.org/blended-learning-definitions-and-models/)

According to Ossiannilsan (2017), there are many models of blended learning. Another one of the common models used by Mountain House High School, Mountain House CA, where blended learning consists of inquiry project-based learning, technological integrated, global connection, games-based learning, direct instruction, peer-to-peer coaching, focus on mastery and virtual learning platforms as shown in Figure 4. 


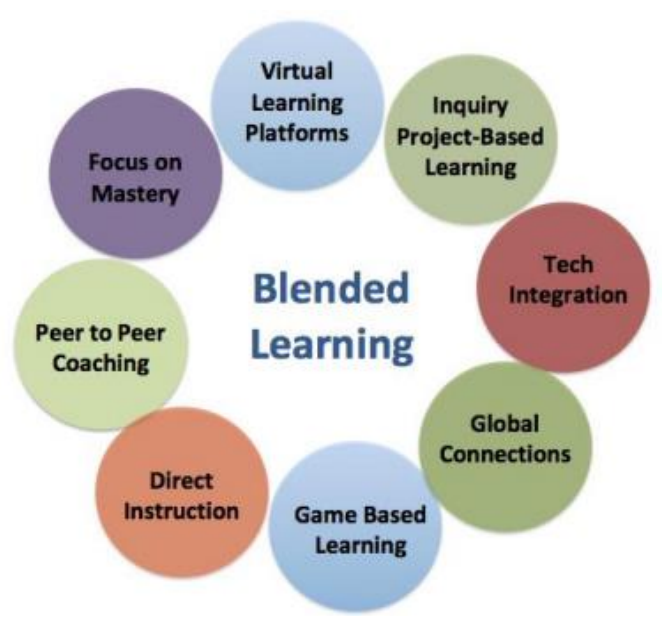

Figure 4: The "blend" in the blended learning model used by Mountain House High School, Mountain House, CA

International Association for K-12 Online Learning (iNOCOL) framework focuses on how engaging, efficient and effective learning begins with specific mind sets. There are 12 key competencies identified by iNOCOL framework for online and blended learning that are combined into four larger domains as illustrated in Figure 5. This framework emphasised the mind-set, quality and skills (competences) that support the creative and continuous improvement of practitioners as well as their ability to thrive in the midst of change. This framework adapted from TPACK (Technology, People, Assessment, Content and Curriculum) model, a framework for understanding quality online teaching combines which discusses all aspects of student-centred functional descriptions of key element approach to educational transformation systemic. This framework assists educators in understanding their evolving roles in blended learning environment by offering insight into the knowledge, skills and disposition need for successful implementation of new instructional methods.

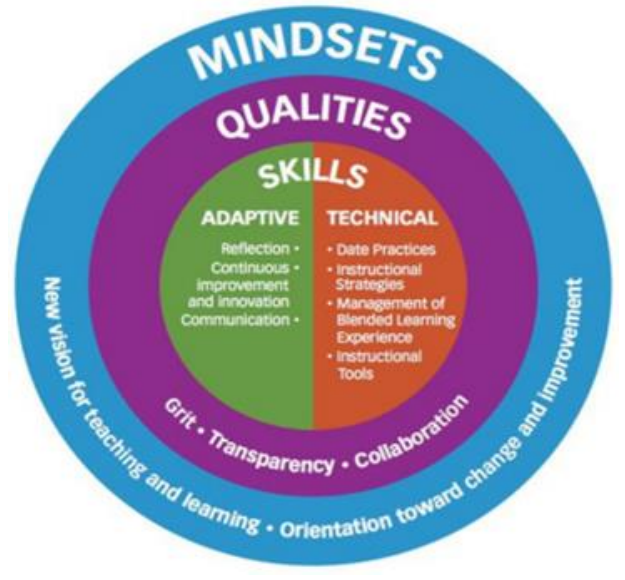

Figure 5: The iNOCOL framework for blended learning

According to Ossiannilsson (2018), the substitution augmentation modification redefinition model (SAMR) by Puentedura (n.d) is insightful for implementation or improvement of the quality of blended learning. The model offers method for determining impact of computer technology on teaching and learning. The SAMR model also provides 


\section{DEVELOPMENT}

Vol. 11, No. 1, 2022, E-ISSN: 2226-6348 @ 2022 HRMARS

indicators of progress that are often followed by users of educational technology as they learn to use it in teaching and learning as shown in Figure 6.

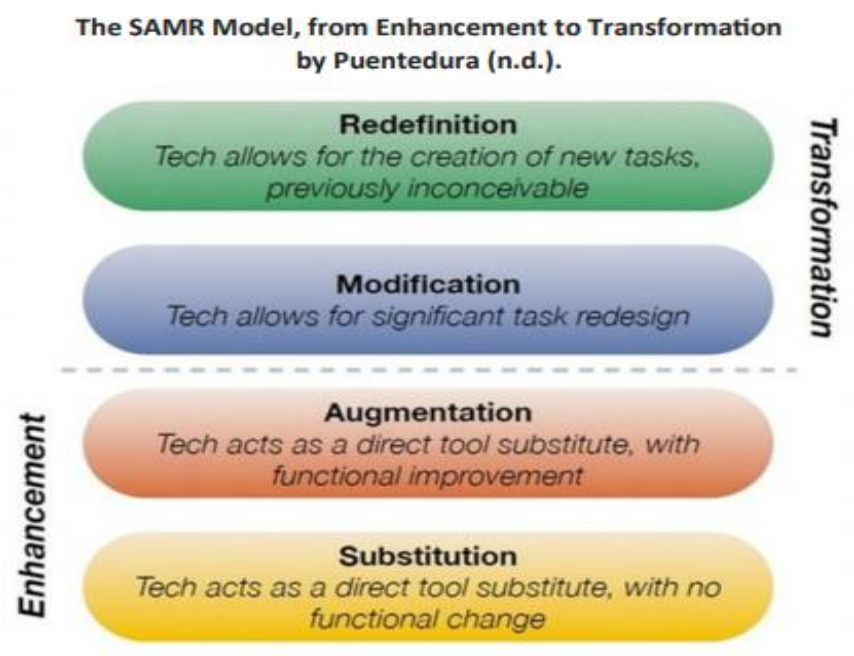

Figure 6: The SAMR model

Ossiannilsson et al (2015) stated to make a successful transition to blended learning, the selection of any model of blended learning must be flexible, and agile enough to adapt to emerging developments in the subject area, level of maturity and incentives to ensure the quality of education offered by institution.

\section{Blended Learning in TVET}

Technical and Vocational Education and Training is a practical-oriented approach that prepares young people with the knowledge and skill required in the workplace. According to United Nations Organisation for Education, Science and Culture (UNESCO), TVET has been called many names such as apprenticeship training, vocational education, technical education, technical-vocational education, occupational education, vocational education and training, professional and vocational education, career and technical education, workforce education, workplace education and other.

The United Nations Organisation for Education, Science and Culture (UNESCO, 2015) stated that TVET is a comprehensive term of a study of technologies and related fields of knowledge that is primarily concerned with the world of work. A study conducted by the International Labour Organization (ILO, 2016) highlighted that technical knowledge is important and it needs to keep up with constant technological changes to incorporate soft skills with their training curriculum to produce creative and collaborative workers.

The use of information and communication technology (ICT) is proven to add value to teaching and learning in TVET. ICT offers transformational pedagogy to enhance the acquisition of relevant skills for example simulation software and computer-supported collaborative learning enhancing the relevance of specific skills. The application of ICT in TVET can enhance the acquisition of skills and through learning engagement and social learning. Using ICT with blended learning and flipped classroom techniques can help students to 
prepare for the classroom discussion and activities whereby they can share their ideas and expand knowledge.

Blended learning in TVET defines the practice of building competence in knowledge and practical and soft skills through combination of face-to-face and technology enabled learning experiences. Distance learning is where the blend allows students to develop competencies online or in their workplace or community and does not require them to attend a physical campus. Figure 7 describes the modes of delivery in implementing of elearning TVET program by Technical Education and Skill Development Authority Philippines (TESDA, 2019). From the framework, TVET mode delivery can be divide into two categories which are face-to-face and eLearning. Face-to-face in blended learning can be conducted in in Competency-Based Training and scheduled through the LMS. The students should be not exceeding 25 per session.

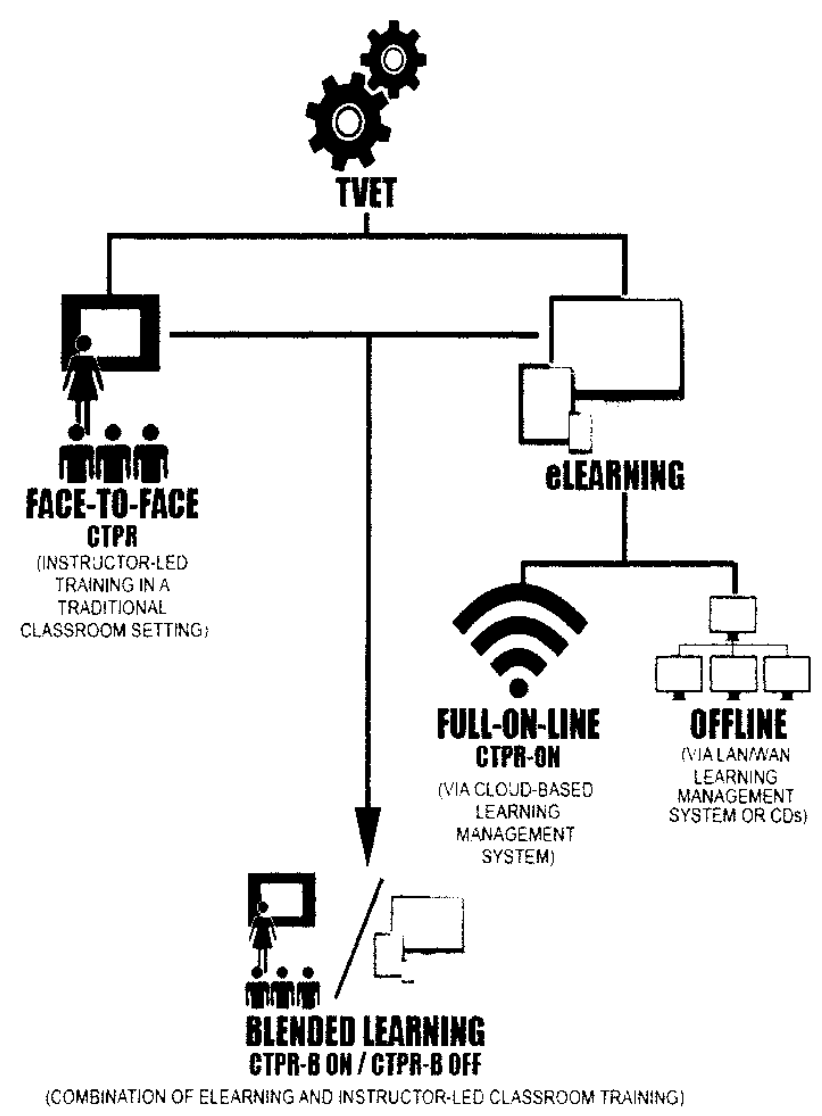

Figure 7: Combination E-Learning and Instructor-Led Classroom Training

(TESDA, 2019)

According to TESDA Circular (2019), blended learning refers to:

i. the combination of online and supervised workshop training where the knowledge and theories are conducted through the Internet and supervised workshop training are conducted face-to-face (TVET Glossary of Term 2017).

ii. learning or training events or activity where e-learning and its various form are combined with more traditional forms of training such as classroom (TVET Glossary of Term 2017). 


\section{DEVELOPMENT}

Vol. 11, No. 1, 2022, E-ISSN: 2226-6348 @ 2022 HRMARS

iii. a strategic and systematic approach to combine times and modes of learning, integrate the best aspects of face-to-face and online interaction with appropriate ICTs (Saliba, Rankine and Cortes, 2013)

iv. the formal education program in which students learn at least in part through the line delivery of content and instruction, with some element of student control over time, place, path and pace and at least in part at a supervised brick-and-mortar location. Blended learning includes an intentional shift to online instructional delivery for a portion of the course boost learning (Staker \& Horn, 2012)

In Malaysia, there are several technical and vocational higher education institutions carried out research on e-learning which are Universiti Teknologi Malaysia, Universiti Tun Hussein Onn, Polytechnics and Community Colleges (Abd Rashid, 2016). e-Learning strategies have not been widely explored in the Vocational Education system for the learning process in Malaysia. Ayuni (2019) used blended learning to study the impacts on student's writing performance in TVET education. Blended learning improved the class attendance and participation in Vocational College. The use of blended learning such as face-to-face group work session, short lectures, web application and online reflection discussion using Web 2.0 technologies helps to improve the achievement of vocational students.

Based on the previous literatures, there are very limited literature review on blended learning in Public Technical Training Institute such as Institut Latihan Perindustrian (ILP) and Pusat Latihan Teknologi Tinggi (ADTEC) under the Human Resource Department, Ministry of Human Resource. Therefore, this study is intended to understand the application of blended learning to deliver learning objectives in TVET institutions.

During the COVID-19 pandemic, technical and vocational education training (TVET) institutions are closed to curb the spread of the virus. Many TVET institutions switch to blended learning as a platform for organising online teaching and learning. According to Commonwealth of Learning (COL, 2020), distance and online learning are adopted to ensure the continuity and upscaling of skills development while keeping communities safe. TESDA Circular (2020) issued the Guidelines in Implementing Flexible Learning in TVET. Figure 8 illustrates the innovation adoption and flexible learning in continuing the delivery TVET, making TVET resilient to educational disruptions and meet the challenges of the digital economy (TESDA, 2020). There are four modes on flexible learning delivery which are faceto-face learning, online learning, blended learning and distance learning. 


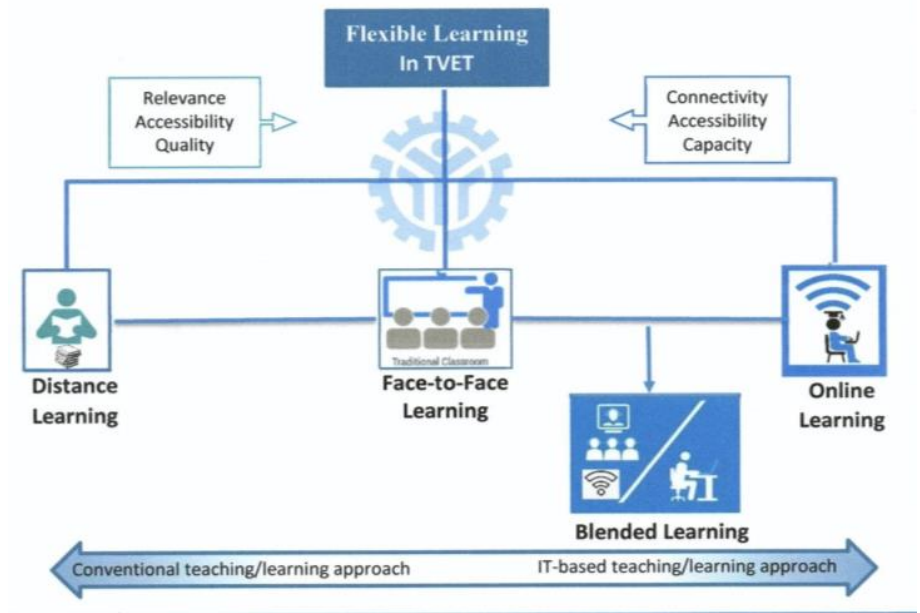

Figure 8: The Conceptual Framework of Flexible Learning (TESDA, 2020)

The combination of distance learning, face-to-face and online learning in TVET institution during the COVID-19 pandemic are effective to limit the spread of the virus. In Malaysia, Shukri (2020) who is a director-general of Department of Skills Development (JPK), Ministry of Human Resources said that both theory and practical components of TVET can be conducted online if they meet the Performance Criteria and Assessment Criteria .All the criteria listed in the guideline include safety, attitude and application of equipment aspect as set out in the National Occupational Skill Standard. The TVET action committee also appealed for immediate online learning and teaching via blended learning platform such as Google Classroom, Zoom, Skype, WhatsApp and Telegram.

According to Commonwealth of Learning (COL, 2020), blended learning in TVET can be categorised into three models in order to increase distance and flexibility:

\section{i. Learning in classroom and workshop, enhanced with technology}

The main teaching and learning process happen in classrooms and workshops within TVET institutions. Technology is used to improve the quality of learning.

ii. On-the-job training supplemented with classroom and distance and online learning Apprenticeship skills have been transferred through experienced artisans and trained students at their workplace. In developing countries, apprenticeship allows young people first gain skills for employment and upskilling. For standardisation and quality assurance apprenticeship, formal technical institutions have taken on the role of teaching theory through day off, block courses, night class or distance learning and assessment and awarding qualifications. Technical institutions can support and evaluate students by visiting the workplaces to ensure coherent and assure quality.

iii. $\quad$ Fully distance and online learning

TVET courses can be done online, where skills can be developed without expert context. Students still need to develop their practical skill at home or workplace. The increase of cloud environment allows ICT skills such as programming or graphic design to be learnt and practiced remotely. 
DEVELOPMENT

Vol. 11, No. 1, 2022, E-ISSN: 2226-6348 @ 2022 HRMARS

Benefit of Blended Learning in TVET

There are many benefits of blended learning in TVET. Terry Neal (2020) in COL stated that Blended Learning TVT offer the several benefits:

\section{i. Increase access}

Students take learning where they are and can access through flexibility of time and space, therefore giving them more choice of where and when to learn. This enables students who need to combine study with after working and who find it difficult to travel to technical institutions.

\section{ii. $\quad$ Reduce cost}

The costs of early development of quality materials are important but can be lower per students if used at scale such as within centrally managed TVET systems with national qualification. The content and learning activities with the materials can reduce variable costs per students. The automated theory assessment can reduce the teachers marking time. Gathering evidence of competency using technology can bring down the cost of processing evidence between teachers, accessors, verifiers, moderators and supervisor. The students traveling cost can be saved by taking learning at their location.

To create specialised context on campus for practical skill development need an up to date physical building and equipment and need expensive cost. Blended learning can maximise the use of building infrastructure by reducing the time students need to present in the institute by redesign and scheduling.

\section{iii. Improve quality}

Distance and blended learning for TVET embedded digital literacy skills and lifelong learning skills which are added value by the employer. Using the multimedia medium such as audio and video can communicate with knowledge effectively, demonstrate practical skills and reduce use assessment written as a proxy for competence nonliteracy skills. The online environment provides a system to share, validate, track and store various evidence formats and enable in timely manner communication between trainees, assessors, verifiers, moderators and trainee support persons.

\section{iv. Increase inclusion}

The blended learning TVET increases the participation from disabilities people. According to Sarton and Smith (2018) people with disabilities make up 15\% of the global population and an estimated 785 million people of working age. Blended learning and information technology development will help them to learn and work.

Challenges of Blended Learning in TVET

There are some of challenges of implementing blended learning in TVET:

\section{i. System Changes to Gain Benefits}

The cost will increase if the use of technology layer on top of existing classroom models and access remains unchanged. To achieve this benefit, it is necessary to revise the role 
of learning, assessment, students support and role of teachers. The solution needs to apply different business model and requires active participation from government and institutional leader.

\section{ii. Increase Cost to Students}

Blended learning increases cost to learner such as cost of devices, data and also electricity. Limited internet access at the rural area is another major issue.

\section{iii. Maintaining Agility}

The quality of blended learning in TVET depends on pre-delivery design and development of quality learning and assessment materials. The prototype guidelines tools and informed checklist can help to accelerate the development of temporary material maintaining quality.

\section{Blended Learning in TVET via Google Classroom}

Learning Management System (LMS) is a software application for managing, recording, tracking, reporting and providing educational courses or training program (Ellis, 2009). LMS provides learning management platform for teachers and student to interact. The available software for LMS are ACS, Blackboard, Moodle, Canvas, Google Classroom and others. Google Classroom is a multi-platform LMS application which users can use for a certain period of time for free. According to Ressler Gene (2017), Google Classroom is a hybrid learning platform developed by Google for schools to promote the creation, distribution, and distribution of tasks in a paperless manner. Google Classroom its user-friendly make it suitable learning management system (LMS) for students of all ages and for all the subject.

Google Classroom is a free learning application for school and non-profit organization and anyone who owns Google account. The scholars found that Google Classroom supports blended learning without additional cost (Dziuban \& Moskal, 2011; Dziuban et al., 2011; Means et al., 2013; Iqbal, Hassan \& Ali, 2015). According to Nieves (2019), there are millions of teacher and students use Google Classroom for work, collaboration and learning.

Google Classroom application is a blended learning method for facilitating studentcentred interaction and student-teacher interaction which allow easier task distribution and assessments. This application enables students to submit assignments and assessments online for assessment within a set date. Similarly, instructors manage the learning development of each student, and they are also able to comment on students leading to the modification of their work. Definitely, the Google classroom can play an important role for students and educators. Ciudad-Gomez (2011) stated that the Google classroom works in promoting training and can use it easily whenever a demand arises. The important task of educators is to make students familiar with Google classroom applications.

Google Classroom allows educators to create assignment, send announcement and start class discussion directly. The students can share their resources and direct interact in Google Classroom. Google Classroom can be accessed not only from your computer or laptop but also with your iPad, tablet and smartphone so that it can be access easily at anywhere and anytime. The platform can be an instructional tool for improving ICT learning in TVET education. Students and teachers that have Google Apps can use Google Classroom for 
Education, a free productivity tool include Gmail, Doc and Drive. According to Ressler, Gene (2017). Google Classroom features are:

\section{i. Assignment (task)}

All task is stored and rated in a series of Google productivity applications and enabling collaboration between teachers and students. Teachers can reuse existing template so the students revert the file back on top of the option to attach additional document that comes with their work.

\section{ii. Rating (measurement)}

There are many scoring schemes supported by Google Classroom. Teachers can monitor the progress of each students, evaluate and return the comment to the students. Similarly, students can view the comment and mark for their assignment.

\section{iii. Communication}

Two-way communication between teacher and students is doable. YouTube video and Google Drive can be connected to the stream for content sharing. Teacher also can use Gmail to send e-mail to one or extra students in the Google Classroom.

\section{iv. Time price (saving time)}

Teacher can send the class code for add students to classroom. Teacher can reuse announcement, assignments, quiz and question for the difference classes. Student's works such as assignments, questions, grades and all comments can be arranged with content that want to review.

\section{v. Archive path (program archive)}

Google Classroom enable teachers to file publications. Classroom from the dashboard can be removed to archive path. The archived classroom still available for teacher to refer to.

\section{vi. Mobile app}

Google Classroom apps is available for iOS and Android devices. This apps allows users to take photos and paste onto the tasks and share the file and support offline access.

\section{vii. Privacy}

There are no display ads on the students and teacher interface. Google classroom is part of $\mathrm{G}$ Suite for Education hence it is free from any advertisements.

Teachers can use all these features during the teaching and learning activities. Through the Google support, teachers can use YouTube in Google Classroom channels. Fisher et al (2017) highlighted the method to use online bricks and mortars samples to provide content in these countries more flexible new ways.

Implementation of Google Classroom by Using ADDIE Model

ADDIE model design is the most popular model to create instructional model. According to Wang and Hsu (2009), ADDIE is a guide to construct software and learning material based on needs. Figure 9 shows the ADDIE instructional design model that can help 
DEVELOPMENT

Vol. 11, No. 1, 2022, E-ISSN: 2226-6348 @ 2022 HRMARS

to organise and streamline the implementation of Google Classroom. ADDIE stands for Analysis, Design, Development, Implementation and Evolution.

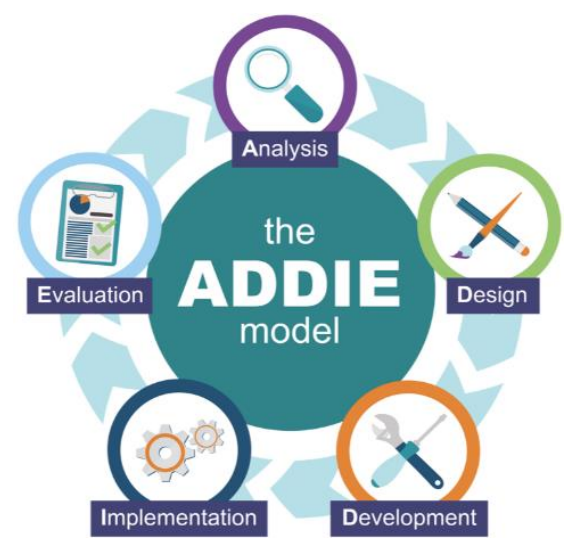

Figure 9: ADDIE Model

(https://amphigean.com/2020/07/29/addie-model-what-is-it-and-why-is-it-useful/)

In the analysis phase, researchers need to conduct analysis of the needs and the characteristic of students in learning to determine the teaching material, learning objective and learning media. The second phase is design where the researchers start to design learning material based on the previous analysis. The third phase is development where teaching plan and learning materials which include text documents, images, video and other support documents are prepared.

The fourth phase is the implementation of blended learning through Google Classroom. The lecturer gives necessary briefing to the students prior to the sessions. The face-to-face learning is two hour per week whilst continuing online learning is one hour per week. Lecturer will upload weekly learning material, assignment and information and students need to stay alert for that. This learning plan is usually for one semester. The final phase is evaluation. There are two phases of evaluation which are formative and summative evaluation. The formative assessment evaluates every phase of the process to ensure the effectiveness of all levels. Summative assessment involves the design of a specific test which the user needs to give their feedback such as content, strategy and multimedia element. The evaluation emphasises the strength and weakness of the learning process.

The first step to create Google Classroom is by signing up with Google Classroom (https://classroom.google.com). Then, the teacher can create classes with Gmail ID and password. The students can join the classroom with 2 options; by using the secret class code or invitation by the teacher. Teacher need to furnish by filling the information such as class name, section, subject and room. Teachers can create difference classroom for difference subject with one Gmail ID which help teachers to deliver learning activities at the same time. The teacher is the moderator for the Google classroom and the students are the member of the classroom. Figure 10 shown classrooms for various subjects. 


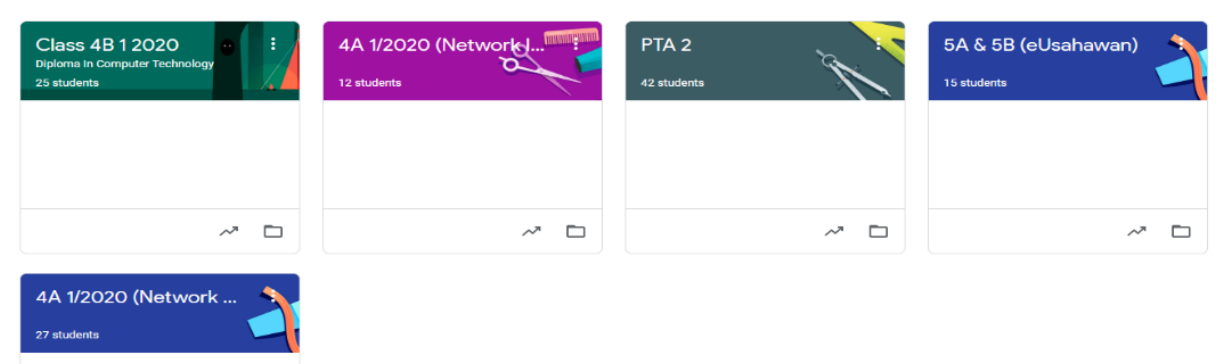

Figure 10: Design and separate 'classroom' for organisation

Figure 11 shows the 4A Semester 1/2020 classroom for subject Network Procurement. The venue is at Lab 6 and 2 credit hours are given for this subject.

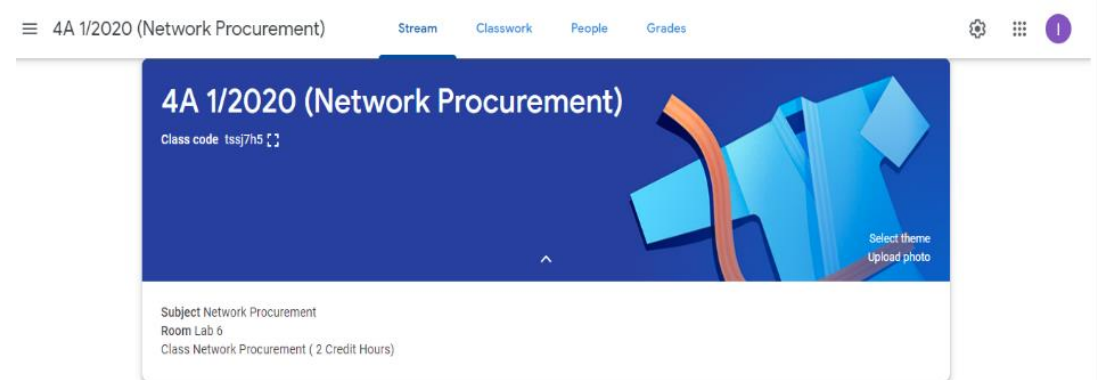

Figure 11: Subject Overview

Figure 12 shows that there are 27 students in Network Procurement classroom. This class is for students $4 \mathrm{~A}$ only. There can be more than one teacher in the same classroom.

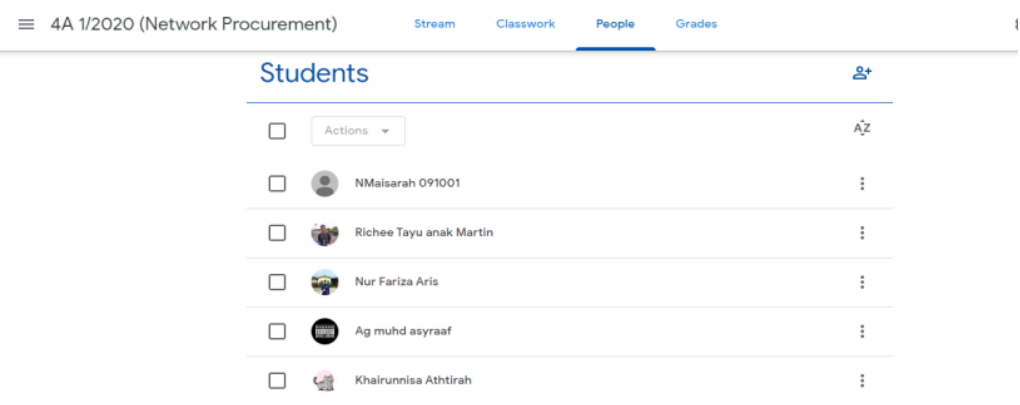

Figure 12: Students in Network Procurement Classroom

Teacher can set the learning outcome and objective of the subject. A thorough learning outcomes and objective provides an overview of the topic. Figure 13 illustrates the learning outcomes for Network procurement subject and the objective of the subject. 


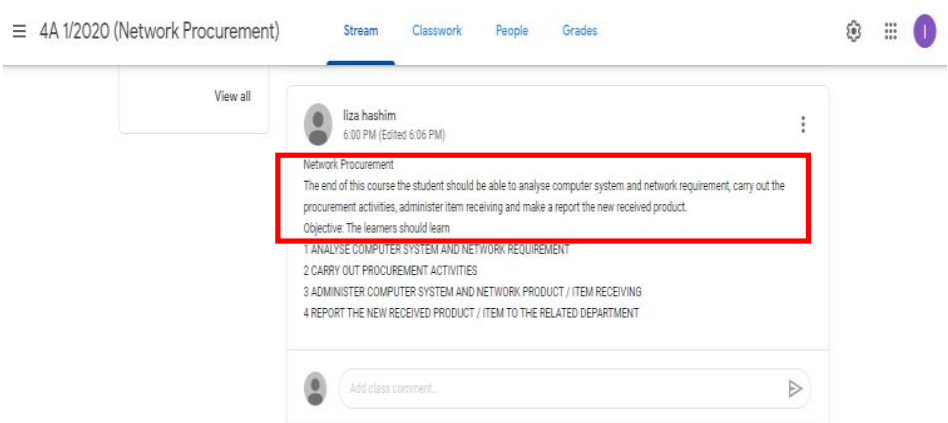

Figure 13: Learning outcomes ana ıesson opjectıves

A teacher can assign different tasks such as learning material, assignment, quiz, and other topic to the students. Figure 14 shows the teacher uploaded the 'Warranty Notes' and the students need to respond and comment to that post. Feedback from teacher can make the learning activities more interactive on top of positive response from students.

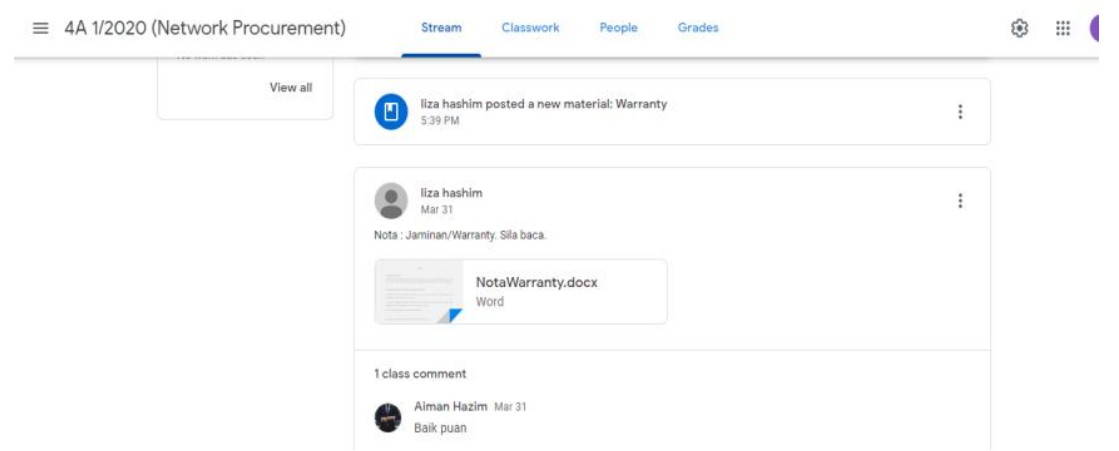

Figure 14: Upload the note

Google Classroom supports the cognitive development of the students. They need to constantly aware of the deadline and submit the task accordingly. Figure 15 shows the assignment post and due date.

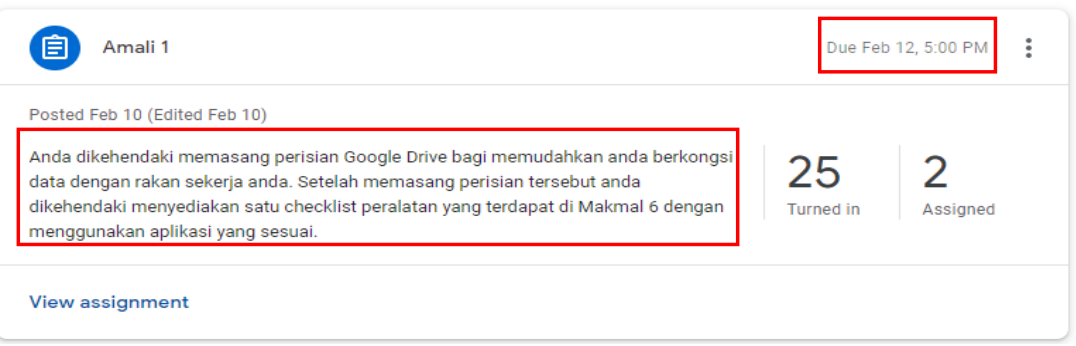

Figure 15: Question and due date in an assignment post

The students have the opportunity to develop their social presence with the Google Classroom through risk-free expression and affective comments. They are also free to stay connected outside the curriculum hours. Figure 16 shows the social presence activities between the students and teacher. 


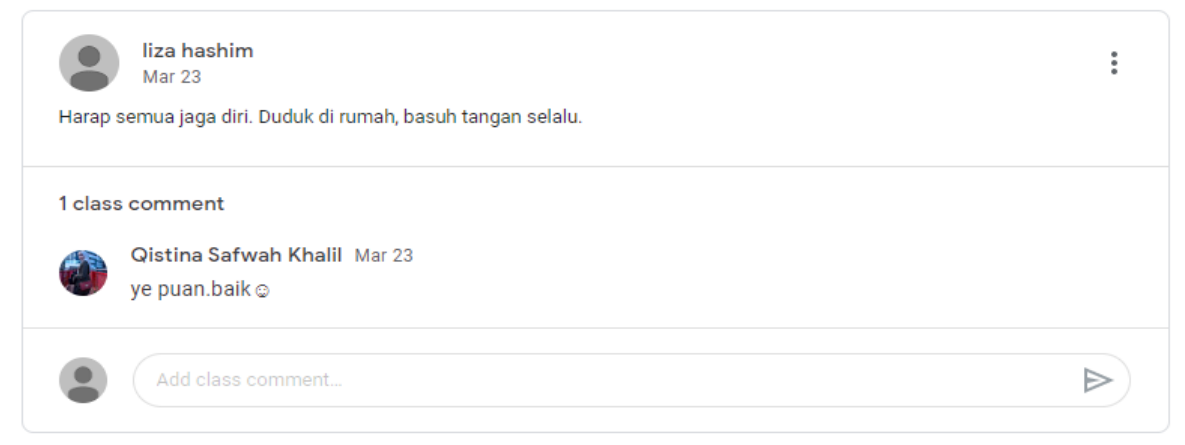

Figure 16: Social presence activities

The teacher graded the student's assignment on Google Classroom platform and provided feedback for students' reference as illustrated in Figure 17. Assigned task, due dates and corresponding marks are tabulated separately.

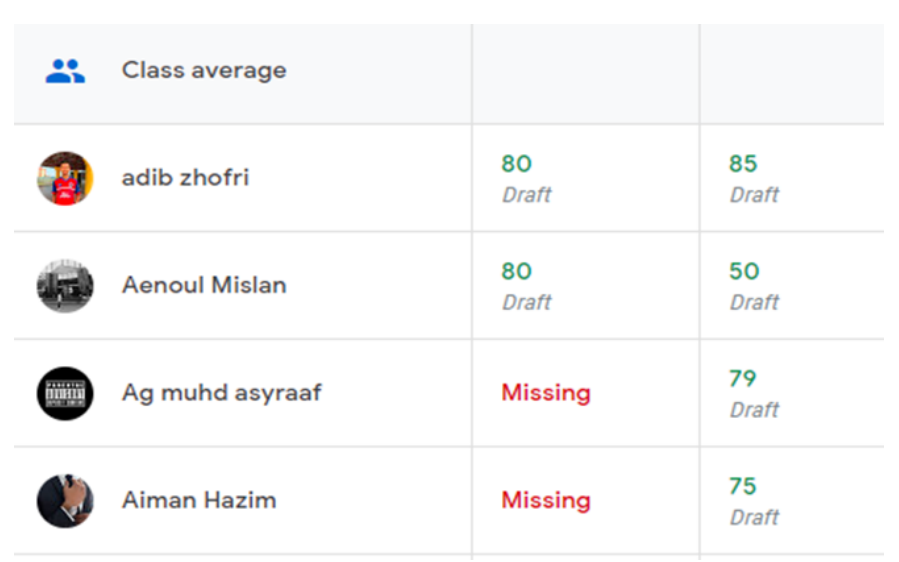

Figure 17: Students Grading

Google classroom offers a seamless opportunity for teachers and students to interact and collaborate in classroom. Other Google apps such as Google Docs, Form, Sheets and Slides are useful for students to utilise. For example, when the teacher assigns the students to prepare a writing portfolio, they can use Google Docs and directly save in Google drive. It enables teachers to monitor the students' works and keep track of changes. Teacher and students can manage their work by sharing ideas as well as engaging with peers.

\section{Conclusion}

In the dynamic landscape of innovation and technology, blended learning should be part of TVET teaching and learning approach. This paper highlights the need and potential to integrate the blended learning approach in TVET learning system. There are several technical and vocational higher education institutions that have carried out research on e-learning such as Universiti Teknologi Malaysia, Universiti Tun Hussein Onn, Polytechnics and Community Colleges. To date, the blended learning approach is less studied in Public Technical Training Institute, thus this study is significant to understand the application of blended learning in Institut Latihan Perindustrian (ILP) and Pusat Latihan Teknologi Tinggi (ADTEC). 
The integration of blended learning with technology models of work and communitybased learning have the potential to increase the employability of the students. During the COVID-19 pandemic, blended learning adoption is an innovative way to ensure education and interaction continuity between students and teachers.

The application of ADDIE model in implementing Google Classroom as a blended learning platform in TVET institution is a process to meet the challenges of $21^{\text {st }}$ century learning skills. This application plays a prominent role in current educational system. Teachers should assist the students to be familiar with the classroom application so that they can feel comfortable and remain active in sessions. Google Classroom features such as assignment rating, communication, time price, archive path, mobile apps and privacy should be extensively utilised to allow students to work, study and collaborate via Google Classroom. Soft skills such as critical thinking and creative skills can be nurtured from blended learning and these skills are highly demanded by employers. Therefore, the implementation of blended learning will increase the quality of teaching and learning in TVET which embeds digital literacy skill, reduce operational cost and more inclusive.

\section{Corresponding Author}

Norliza Hashim

Open University Malaysia Malaysia

Email:ijot76@oum.edu.my

\section{References}

Abd Rashid, Z. (2016). Review of web-based learning in TVET: History, advantages and disadvantages. International Journal of Vocational Education and Training Research, 2(2), 7. https://doi.org/10.11648/j.ijvetr.20160202.11

Attaran, M., \& Zainuddin, Z. (2018) How Students Experience Blended Learning (Malaysian Experience). Interdisciplinary Journal of Virtual Learning in Medical Sciences 2018 June; 9(2): e79384. doi:10.5812/ijvlms.79384.

Adams, B. S., Brown, M., Dahlstrom, E., Davis, A., DePaul, K., Diaz, V., \& Pomerantz, J. (2018). NMC Horizon Report: 2018 Higher Education Edition. Louisville, CO: EDUCAUSE.

Banditvilai, C. (2016). Enhancing students' language skills through blended learning. The Electronic Journal of e-Learning, 14(3), 220-229

Commonwealth of Learning. (2015, June 1). Open and distance learning: Key terms and definitions.

Retrieved

from: http://oasis.col.org/bitstream/handle/11599/829/Definitions_ODL\%20key\%20terms_ 20150522.pdf?sequence $=4$ Commonwealth of Learning

Christensen Institute. (2015). Blended learning definitions. Retrieved from https://www.christenseninstitute.org/blended-learning-definitions-and-models/

Christensen, C. M., Horn, M. B., \& Staker, H. (2013). Is K-12 Blended Learning Disruptive? An Introduction to the Theory of Hybrids. Clayton Christensen Institute for Disruptive Innovation.

Ciudad-Gómez A. (2010). Teaching Innovation and Use of The ICT In the Teaching-Learning Process Within the New Framework of the EHEA, By Means of Moodle Platform. American Journal of Business Education (AJBE), 3(13), 13-20. https://doi.org/10.19030/ajbe.v3i13.972 
Dziuban, C., \& Moskal, P. (2011). A course is a course is a course: Factor invariance in student evaluation of online, blended and face-to-face learning environments. The Internet and Higher Education, 14(4), 236-241.

https://doi.org/10.1016/j.ineduc.2011.05.003

Ellis, R. K. (2009). Learning Managament Systems. Alexandria, VI: American Society for Training \& Development (ASTD).

Fisher, J. F., Bushko, K., \& White, J. (2017). Blended beyond borders: A scan of blended learning obstacles and opportunities in Brazil, Malaysia, \& South Africa. WISE.

Garrison, D. R., \& Kanuka, H. (2004). Blended learning: Uncovering its transformative potential in higher education. The Internet and Higher Education, 7(2), 95-105. https://doi.org/10.1016/j.iheduc.2004.02.001

Greitzer, F. L. (2002). A cognitive approach to student-centred e-learning. Proceedings of the Human Factors and Ergonomics Society Annual Meeting, 46(25), 2064-2068. https://doi.org/10.1177/154193120204602515

Gulati, S. (2008). Compulsory participation in online discussions: Is this constructivism or normalisation of learning? Innovations in Education and Teaching International, 45(2), 183-192. https://doi.org/10.1080/14703290801950427

Harasim, L. M. (2017). Learning theory and online technologies. Routledge, Taylor \& Francis Group.

Hannon, J., \& Macken, C. (2014). Blended and online curriculum design toolkit. La Trobe University.

Retrieved

from https://www.latrobe.edu.au/_data/assets/pdf_file/0006/602178/ Blended-learningToolkit-v4.pdf

Hoic-Bozic, N., Mornar, V., \& Boticki, I. (2009). A blended learning approach to course design and implementation. IEEE Transactions on Education, 52(1), 19-30. https://doi.org/10.1109/te.2007.914945

Iqbal, M. N., Hassan, M. U., \& Ali, M. Q. (2015). Assessing quality of English teachers at secondary level in Punjab, Pakistan. Journal of Elementary Education, 25(1), 75-90.

Lim, C. P., \& Wang, L. (2017). Blended learning for quality higher education: Selected case studies on implementation from Asia-Pacific. UNESCO Bangkok Office.

Ministry of Education Malaysia. (2015). Malaysia Education Blueprint 2015-2025 (Higher Education). Retrieved from https://www.um.edu.my/docs/um-magazine/4-executivesummary-pppm-2015-2025.pdf

Murphy, R., Bienkowski, M., Bhanot, R., Wang, S., Wetzel, T., House, A., Leones, T., Van Brunt, J. (2017). Evaluating Digital Learning for Adult Basic Literacy and Numeracy. Menlo Park, CA: SRI International.

Maniar, S. (2017). 9 prerequisites for Using blended learning in classroom teaching. eLearning Industry. Retrieved from https://elearningindustry.com/blended-learning-inclassroom-teaching-9-prerequisites.

Means, B., Toyama, Y., Murphy, R., Bakia, M., \& Jones, K. (2009). Evaluation of evidence-based practices in online learning: A meta-analysis and review of online learning studies.

New TVET Guideline (2020). Retrieved from https://www.thestar.com.my/news/education/2020/05/03/new-tvet-guideline

Nieves, K. (2019). 4 tips for Managing blended learning. Edutopia. Retrieved from https://www.edutopia.org/article/4-tips-managing-blended-learning. 
Norliza and Nornihla. (2020). The Role of Learning Theories in Online Learning for Designing Learning Materials and Instructional Strategies. The Interdisciplinary of Management Economic and Social Research.

Ossiannilsson, E., Williams, K., Camilleri, A. F., \& Brown, M. (2015). Quality models in online and open education around the globe. State of the art and recommendations. Oslo: International Council for Open and Distance Education.

Ossiannilsson, E. (2012). Benchmarking e-learning in higher education. Lessons learned from international projects (Doctoral dissertation, Oulu University, Finland). Retrieved from http://jultika.oulu.fi/files/isbn9789526200415.pdf

Ossiannilsson, E. (2018). Blended Learning in Continuous Vocational Training, and Continuous Professional Development September 2018. 10.13140/RG.2.2.35478.80966.

Puentedura. (n.d.). The SAMR Model: from Enhancement to Transformation. Retrieved from http://www.hippasus.com/rrpweblog/archives/2013/05/29/SAMREnhancementToTra nsformation.pdf

Powell, A., Rabbitt, B., \& Kennedy, K. (Eds.). (2014). iNACOL blended learning teacher competency framework: iNACOL in partnership with The Learning Accelerator. INACOL, The International Association for K-12 Online Learning, Retrieved from https://www.inacol.org/wp-content/uploads/2015/02/iNACOL-Blended-LearningTeacher-Competency-Framework.pdf

Raman, A., \& Rathakrishnan, M. (2020). Blended learning via Google classroom: English language students experience based on UTAUT model and flow theory. Hamdard Islamicus, 43(1\&2), 94-108.

Rosen, D. J., \& Stewart, C. (2015). Blended learning for the adult education classroom. Corvallis, OR: Essential Education. Retrieved from http://app.essentialed.com/resources/ blended-learning-teachers-guide-web.pdf

Ressler, G. (2017). Google classroom: Now open to even more students. Google. https://blog.google/outreach-initiatives/education/google-classroom-now-open-evenmore-students/.

United Nations Educational, Scientific and Cultural Organization. (2015). Recommendation concerning technical and vocational education and training (TVET). Retrieved from http://portal.unesco.org/en/ev.phpURL_ID=49355\&URL_DO=DO_TOPIC\&URL_SECTION=201.html.

Saliba, G., Rankine, L., \& Cortez, H. (2013). Fundamentals of blended learning. Sydney: University of Western Sydney.

Sener, J. (2015, August 17). E-learning definitions. Updated E-Learning Definitions. Retrieved from https://onlinelearningconsortium.org/updated-e-learning-definitions-2/.

Sarton, E. \& Smith, M. (2018) UNICEF Think Pieces Series: Disability inclusion. UNICEF Eastern and Southern Africa Regional Office, Nairobi. Retrieved from https://www.unicef.org/esa/sites/unicef.org.esa/files/2019-

04/EducationThinkPieces_7_DisabilityInclusion. Pdf

Stapa, M. A., \& Mohammad, N. (2019). The use Of Addie model for DESIGNING blended learning application at vocational colleges in Malaysia. Asia-Pacific Journal of Information Technology \& Multimedia, 08(01), 49-62. https://doi.org/10.17576/apjitm-2019-0801-05

Staker, H., \& Horn, M. B. (2012). Classifying K-12 Blended Learning. San Mateo: Innosight Institute, Inc. Retrieved from https://www.christenseninstitute.org/wpcontent/uploads/2013/04/Classifying-K-12-blended-learning.pdf 


\section{DEVELOPMENT}

Vol. 11, No. 1, 2022, E-ISSN: 2226-6348 @ 2022 HRMARS

Siemens, G. (2004). Connectivism: A Learning Theory for Digital Age. Retrieved from https://www.semanticscholar.org/paper/Connectivism\%3A-A-Learning-Theory-forthe-Digital-Age-Siemens/f87c61b964e32786e06c969fd24f5a7d9426f3b4

TESDA Circular. (2019). Guidelines in The Implementing of eLearning TVET Programs. Retrieved from https://www.scribd.com/document/446982460/TESDA-Circular-No104-2019-E-learning2

Theresa, T. T. Y., \& Park, J. (2017). Beyond access: ICT-enhanced Innovative pedagogy In TVET in the Asia-Pacific. UNESCO Bangkok. https://bangkok.unesco.org/content/beyondaccess-ict-enhanced-innovative-pedagogy-tvet-asia-pacific.

Neal, T. (2020). Strategies for Blended TVET in Response to COVID-19. Commonwealth of Learning. Retrieved from https://www.thecommonwealth.io/wpcontent/uploads/2020/07/StrategiesforblendedTVETCOVID19.pdf

UNESCO. (2015a). Education 2030: Incheon declaration and framework for action Towards inclusive and equitable quality education and lifelong learning for all. Retrieved from https://iite.unesco.org/publications/education-2030-incheon-declaration-frameworkaction-towards-inclusive-equitable-quality-education-lifelong-learning/.

UNESCO. (2015b). UNESCO and Education 2030: Framework for action and sustainability development goals 4, SDG4. Retrieved from http://en.unesco.org/sdgs

UNESCO. (2016). Blended learning for quality higher education: Selected case studies on implementation in the Asia-Pacific. Retrieved from http://unesdoc.unesco.org/images/0024/002468/246851E.pdf

Vaughan, N., \& Garrison, D. R. (2006). How blended learning can support a faculty development community of inquiry. Journal of Asynchronous Learning Networks, 10(4), 139-152.

Vaughan, N. D., Cleveland-Innes, M., \& Garrison, D. R. (2013). Teaching in blended learning environments: Creating and sustaining communities of inquiry. AU Press.

Wang, S. K., \& Hsu, H. Y. (2008). Using ADDIE model to design Second Life activities for online students. In E-Learn: World Conference on E-Learning in Corporate, Government, Healthcare, and Higher Education (pp. 2045-2050). Association for the Advancement of Computing in Education (AACE). 